\title{
Retinoid modulation of collagenase production by adherent human mononuclear cells in culture*
}

\author{
AKIHIDE OHTA, ${ }^{2}$ JAMES S LOUIE, ${ }^{2}$ AND JOUNI UITTO ${ }^{1}$ \\ From the Department of Medicine, University of California Los Angeles School of Medicine, Divisions of \\ ${ }^{1}$ Dermatology and ${ }^{2}$ Rheumatology, Harbor-UCLA Medical Center, Torrance, California
}

SUMMARY Previous observations have suggested that retinoids might be useful for the treatment of rheumatoid arthritis. In this study we examined the effects of various retinoids on collagenase production by adherent human peripheral blood mononuclear cells in culture. We have previously shown that these cells, consisting predominantly of monocyte-macrophages, actively synthesise and secrete collagenase upon stimulation with concanavalin A. ${ }^{16}$ The cells were incubated in serum free medium with all-trans-retinoic acid, 13-cis-retinoic acid, all-trans-retinal, or Ro 10-9359 (trimethylmethoxyphenyl retinoic acid ethyl ester) for up to 72 hours, and the collagenase activity was determined with $\left[{ }^{3} \mathrm{H}\right]$ proline labelled type $\mathrm{I}$ collagen as substrate. The incubation of mononuclear cells with all-trans-retinoic acid in the concentration range $10^{-7}$ $10^{-5} \mathrm{~mol} / \mathrm{l}$ resulted in a dose dependent inhibition of the collagenase production. All-trans-retinal was also a potent inhibitor, whereas 13-cis-retinoic acid and Ro 10-9359 in a concentration of $10^{-5} \mathrm{~mol} / \mathrm{l}$ had a lesser effect. Control experiments indicated that the inhibition of collagenase production by all-trans-retinoic acid did not result from inhibition of total protein synthesis nor could it be explained by induction of an inhibitory molecule. These results indicate that retinoids with distinct structural features can inhibit collagenase production by monocyte-macrophages, and suggest a role for retinoids in the treatment of rheumatoid arthritis.

Key word: monocytes.

Retinoid therapy has recently been suggested for rheumatoid arthritis. ${ }^{2}$ This suggestion was based on several experimental observations attesting to the potential efficacy of retinoids as antirheumatic agents. For example, in the adjuvant arthritis experimental model of rheumatoid arthritis the oral administration of 13-cis-retinoic acid (13-cisRA) significantly reduced the joint inflammation in the rat. ${ }^{3}$ Also, adherent cells isolated from the inflamed joints of the rats treated with 13-cis-RA secreted less collagenase than the control cultures. ${ }^{3}$ Furthermore, all-trans-RA, 13-cis-RA, and 4-hydroxyphenylretinamide (4-HPR) have been shown to reduce the production of collagenase by synovial cells in culture. ${ }^{45}$ These observations

\footnotetext{
Accepted for publication 17 October 1986.

Correspondence to Dr Jouni Uitto, Department of Dermatology, Jefferson Medical College, 1020 Locust Street, M46 Philadelphia, PA 19107, USA.

*A preliminary report on this study was presented at the western regional meeting of the Society for Investigative Dermatology, Carmel, CA, 4-7 February 1986.'
}

suggest that retinoids may interfere with collagenase production also in vivo and could be beneficial in the treatment of rheumatoid arthritis. On the other hand, in the collagen induced rat model of arthritis both 13-cis-RA and 4-HPR augmented the inflammatory component of arthritis. ${ }^{6}$ Thus the multiplicity of the effects of retinoids on various animal systems as models for human rheumatoid arthritis, ${ }^{36}$ and the proposed effects of retinoids on cellular metabolism, ${ }^{78}$ require additional studies to establish any validity of retinoids for treatment of rheumatoid arthritis.

Monocyte-macrophages, the hallmark of chronic inflammatory processes, have been shown to synthesise and secrete proteases, including collagenase, which are thought to mediate tissue destruction in diseases. ${ }^{9-16}$ We have recently shown that adherent mononuclear cells cultured from human peripheral blood actively synthesise and secrete collagenase when stimulated with concanavalin $A .^{16}$ The enzyme was shown to be similar to other mammalian collagenases in that it cleaved native type I collagen 
at a single locus three quarters of the chain length away from the amino terminus of the molecule. ${ }^{16}$ The enzyme was shown to be secreted in an active form, but the activity could be enhanced by sulphydryl reagents such as $N$-ethylmaleimide (NEM). ${ }^{16}$ The total cumulative production in a 48 hour culture of the adherent mononuclear cells activated by concanavalin A was shown to be of the same order of magnitude as the enzyme activity present in the same number of polymorphonuclear leucocytes. ${ }^{16}$ Thus collagenase synthesised and secreted by monocyte-macrophages present in rheumatoid synovium may contribute to the connective tissue destruction in this disease. To assess the potential of monocytes as a target for retinoid therapy we have examined in this study the effects of various retinoids on collagenase production in adherent mononuclear cell cultures.

\section{Materials and methods}

\section{RET INOIDS}

All-trans-RA and all-trans-retinal were purchased from Sigma Chemical Co, St Louis, MO; 13-cis-RA and Ro 10-9359 (trimethylmethoxyphenyl RA ethyl ester; etretinate) were obtained from Hoffmann-La Roche, Nutley, NJ. The retinoids were dissolved in ethanol immediately before use and kept in the dark during the procedures. The final concentration of ethanol in cell cultures was $0.19 \%$ or less (except for $5 \times 10^{-5} \mathrm{M}$ all-trans-RA, in which case it was $1 \%$ ). Parallel control cultures were incubated with ethanol alone in the corresponding concentration. Ethanol in $0.2 \%$ concentration was not toxic to the cells, as assessed by $\left[{ }^{3} \mathrm{H}\right]$ leucine incorporation, trypan blue dye exclusion test, or by release of lactate dehydrogenase (LDH) to the medium (see below). Also, $0.2 \%$ ethanol had no effect on collagenase production by these cells. One per cent ethanol inhibited collagenase production in control cultures by $19 \%$.

MONONUCLEAR CELL CULTURES

Blood samples were obtained from healthy volunteers and from a patient with haemochromatosis whose monocytes have been previously shown to be active in synthesising and secreting collagenase even without concanavalin A activation. ${ }^{16}$ Peripheral blood mononuclear cells were isolated by density gradient centrifugation on Ficoll-Hypaque (Histopaque-1077; Sigma Chemical Co, St Louis, MO).${ }^{17}$ The isolated mononuclear cells were pooled, washed in Hanks's balanced salt solution (HBSS), and suspended in serum free Dulbecco's modified Eagle's medium (Gibco, Grand Island, NY) supplemented with $2 \mathrm{mM}$ L-glutamine, $100 \mathrm{U} / \mathrm{ml}$ penicillin, $100 \mu \mathrm{g} / \mathrm{ml}$ streptomycin, and $0 \cdot 2 \%$ lactalbumin hydrolysate (DMEM-LH; Sigma). To estab-? lish the monocyte cultures $2 \times 10^{6}$ cells in $500 \mu \mathrm{l}$ of DMEM-LH were plated in 24-well tissue cultures plates (Corning, NY). The mononuclear cells weres allowed to adhere for $120 \mathrm{~min}$ under $5 \% \mathrm{CO}_{2} / 95 \%$ क air at $37^{\circ} \mathrm{C}$. The medium containing the unadheredo cells was then removed, the adherent cells were washed with $500 \mu \mathrm{l}$ of HBSS, and $500 \mu \mathrm{l}$ of fresh, serum free DMEM-LH was added to the cultures $\overrightarrow{0}$ To enhance the production of collagenase the culture medium was supplemented with $20 \mu \mathrm{g} / \mathrm{m}$ concanavalin A (Difco, Detroit, MI); the retinoidso were added at the same time. The incubations were then continued for varying time periods up to $73 \mathrm{~s}^{\circ}$ hours at $37^{\circ} \mathrm{C}$ under $5 \% \mathrm{CO}_{2} / 95 \%$ air.

COLLAGENASE A S A Y
At different times of cell incubation aliquots of the serum free media were assayed for collagenase activity by a sensitive and specific method. ${ }^{18}$ In these assays $\left[{ }^{3} \mathrm{H}\right.$ )proline labelled, native, triple helical type I collagen, with a specific activity of $2.27 \times 10^{4} \mathrm{cpm} / \mu \mathrm{g}$, was used as substrate. Details ${ }^{\mathrm{V}}$ of this assay procedure have been reported previously. ${ }^{18}$ Briefly, in a standard assay the subs trate $\left(3 \times 10^{4} \mathrm{cpm}\right.$ in $20 \mu \mathrm{l}$ of $0.01 \mathrm{M}$ acetic acid) was mixed with $10 \mu \mathrm{l}$ of $0.5 \mathrm{M}$ TRIS (trometamol)- $\mathrm{HCl}$ pH $7 \cdot 8$, containing $2 \cdot 0 \mathrm{M} \mathrm{NaCl}, 0 \cdot 1 \mathrm{M} \mathrm{CaCl} 2$ and $0.1 \mathrm{M} \mathrm{NEM}$, and with $10 \mu \mathrm{l}$ of a solution containing bovine serum albumin, $0.2 \mathrm{mg} / \mathrm{ml}$. Aliquots $(60 \mu \mathrm{l}$ of the tissue culture supernatant to be assayed for collagenase activity were then added, and the incubations were continued for $120 \mathrm{~min}$ at $37^{\circ} \mathrm{C}$. The collagenase digestion was stopped by the addition of $50 \mu \mathrm{l}$ of $0.2 \mathrm{M}$ disodium ethylenediaminetetrae acetate ( $\mathrm{Na}_{2}$ EDTA). Unlabelled soluble type $\bar{P}$ collagen, trypsin, and $\alpha$-chymotrypsin, in fina $\$$ concentrations of $0.2,0 \cdot 16$, and $0.16 \mathrm{mg} / \mathrm{ml}$ respec 3 tively, and dissolved in $0.2 \mathrm{M} \mathrm{NaCl}$ and $50 \mathrm{mM}$ TRIS- $\mathrm{HCl}, \mathrm{pH} 7 \cdot 5$, were then added to give a finat volume of $400 \mu \mathrm{l}$; the incubations were continued fo. another 20 minutes at $37^{\circ} \mathrm{C}$. An equal volume oq $20 \%$ ice cold trichloroacetic acid (TCA) was ther added, and the undigested $\left[{ }^{3} \mathrm{H}\right]$ proline labellegt substrate was precipitated by centrifugation. The radioactivity in the supernatant, representing colo lagen degradation, was counted with a liquid scint tillation counter (Beckman LS-7500). In each assaf a set of control tubes containing medium nợ incubated but containing trypsin and $\alpha$-chymotrypo sin was included. Collagenase activity was expressed in units $(\mathrm{U})$, where $1 \mathrm{U}$ equals $1 \mu \mathrm{g}$ collage degraded per minute.

For assay of intracellular collagenase activity the medium was removed and the adherent monocytes 
were rinsed with phosphate buffered saline. DMEM-LH, $500 \mu \mathrm{l}$, was added to each well, the cells were then detached by scraping with a rubber policeman and homogenised with a Teflon glass tissue homogeniser at $4^{\circ} \mathrm{C}$. The homogenates were centrifuged at $18000 \mathrm{~g}$ for $20 \mathrm{~min}$, and the supernatants were assayed for collagenase activity as above.

\section{OTHER ASSAYS}

Total protein synthesis by the cultured mononuclear cells was assayed by incubation of the cells with $1 \cdot 11$ $\mathrm{MBq}$ of $\left[\mathrm{L}-4,5-{ }^{3} \mathrm{H}\right]$ leucine (specific activity 5.59 $\mathrm{TBq} / \mathrm{mmol}$; Amersham) under conditions identical with those used for collagenase production. At the end of incubation protease inhibitors were added to the following final concentrations: $\mathrm{Na}_{2}$ EDTA $(10 \mathrm{mmol} / \mathrm{l})$, NEM $(10 \mathrm{mmol} / \mathrm{l})$, and phenylmethylsulphonyl fluoride $(0.3 \mathrm{mmol} / \mathrm{l})$. The adherent cells were detached by brief sonication, and the $\left[{ }^{3} \mathrm{H}\right]$ leucine labelled macromolecules in combined medium and cell fractions were precipitated by the addition of an equal volume of $20 \%$ TCA. The TCA precipitates were collected on Millipore prefilters (Millipore, AP1502500, Millipore, Bedford, MA) on a vacuum manifold. The filters were air dried and counted in a Beckman LS-7500 liquid scintillation counter, as described previously. ${ }^{16}$

The viability of mononuclear cells was estimated by a trypan blue dye exclusion test. ${ }^{19}$

The LDH activity in the culture medium was

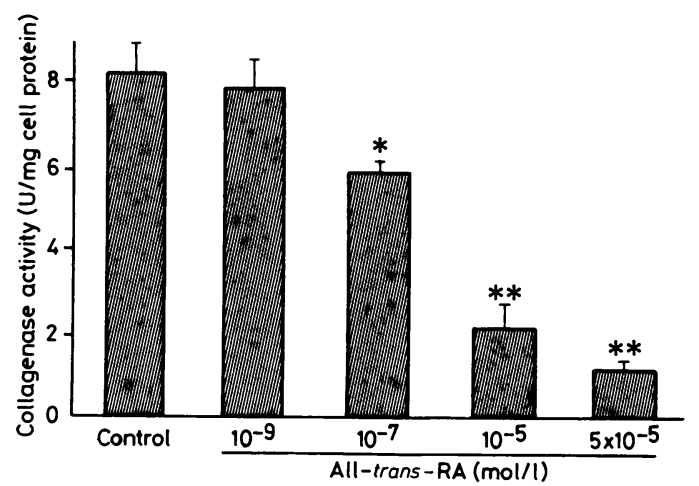

Fig. 1 Dose dependent inhibition of collagenase production by all-trans-retinoic acid (all-trans-RA) in adherent human mononuclear cell cultures. Peripheral blood mononuclear cells isolated from a patient with haemochromatosis were incubated with all-trans-retinoic acid in the concentrations indicated for 72 hours.

Collagenase activity was determined as indicated in 'Materials and methods'. The values are mean (SEM) of four parallel determinations. The statistical significance of the difference, calculated by Student's t test, is indicated in the figure $(p<0.05$; $p<0 .(01)$.

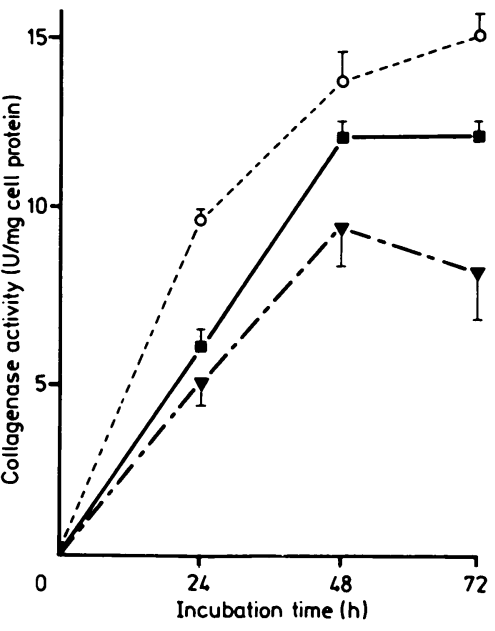

Fig. 2 Time dependent inhibition of collagen production by all-trans-retinoic acid. Adherent human mononuclear cells from a patient with haemochromatosis were incubated as in Fig. I either without $(\bigcirc)$, or with $10^{-6} M(\mathbf{\square})$ or $10^{-5} \mathrm{M}(\boldsymbol{\nabla})$ all-trans-retinoic acid. The collagenase activity was determined at the times indicated as described in 'Materials and methods'. The values are mean (SEM) of four parallel determinations.

assayed by a modification of the method of Wroblewski and $\mathrm{LaDue}^{20}$ using a commercial kit (Sigma Chemical Co).

The protein content of cell homogenates after sonication was assayed by a colorimetric method ${ }^{21}$ using commercial reagent (Bio-Rad Laboratories, Richmond, CA).

STATISTICAL ANALYSIS

The results were evaluated for statistical significance by Student's $t$ test.

\section{Results}

INHIBITION OF COLLAGENASE PRODUCTION BY ALL-TRANS-RETINOIC ACID

The effect of retinoids on collagenase production by adherent human mononuclear cells was first studied by incubating cells isolated from the blood of a patient with haemochromatosis in the presence of varying concentration of all-trans-RA. A dose dependent inhibition of collagenase production was noted in the concentration range $10^{-9}-5 \times 10^{-5} \mathrm{~mol} / \mathrm{l}$ (Fig. 1). The mean inhibition by $10^{-5} \mathrm{M}$ all-trans$\mathrm{RA}$ in three independent experiments was 64.7 $(16 \cdot 3) \%$ (mean (SD)) when compared with control cultures incubated with $0 \cdot 2 \%$ ethanol alone. The inhibition by $10^{-6} \mathrm{M}$ and $10^{-5} \mathrm{M}$ all-trans-RA was also shown to be time dependent (Fig. 2). Similar 
inhibition of collagenase production was also observed in monocyte cultures established from two healthy volunteers; these cell cultures required the presence of concanavalin A for collagenase production. In the cultures established from healthy subjects $10^{-5} \mathrm{M}$ all-trans-RA inhibited the collagenase production by $60.6(2 \cdot 6) \%$ (Table 1 , experiment 2 ) and $58 \cdot 1(5 \cdot 1) \%$ respectively (mean (SD)).

To examine the specificity of all-trans-RA on collagenase production several control experiments were performed. Firstly, the total protein synthesis was determined by incorporation of $\left[{ }^{3} \mathrm{H}\right]$ leucine in the cell cultures. The results indicated that the incorporation of radioactivity into protein in the control and $10^{-5} \mathrm{M}$ all-trans-RA treated cultures was $1.62(0 \cdot 05) \times 10^{4}$ and $1.35(0 \cdot 21) \times 10^{4} \mathrm{cpm} / 2 \times 10^{6}$

Table 1 Effects of various retinoids on collagenase production by adherent human mononuclear cells in culture*

\begin{tabular}{|c|c|c|c|c|}
\hline \multirow[t]{2}{*}{$\begin{array}{l}\text { Retinoid } \\
\text { tested }\end{array}$} & \multirow[t]{2}{*}{$\begin{array}{l}\text { Concentrution } \\
\text { (mol/l) }\end{array}$} & \multicolumn{2}{|c|}{$\begin{array}{l}\text { Collagenase } \\
\text { production }\end{array}$} & \multirow[t]{2}{*}{$p$ Value $\div$} \\
\hline & & $\begin{array}{l}\text { (U/mg cell } \\
\text { protein) }{ }^{*}\end{array}$ & $\begin{array}{l}\% \text { of } \\
\text { control }\end{array}$ & \\
\hline \multicolumn{5}{|l|}{ Experiment 1: } \\
\hline Nonc (control) & - & $6 \cdot 7(0 \cdot 6)$ & $1(0) \cdot 0$ & - \\
\hline $\begin{array}{l}\text { All-trans-RA } \\
\text { All-trans-RA }\end{array}$ & $\begin{array}{l}10^{-6} \\
10^{-5}\end{array}$ & $\begin{array}{l}3 \cdot 9(0 \cdot 1) \\
1 \cdot 4((0 \cdot 1)\end{array}$ & $\begin{array}{l}58 \cdot 2 \\
2(0 \cdot 9\end{array}$ & $\begin{array}{l}<0 \cdot(01 \\
<(0 \cdot()(0) 1\end{array}$ \\
\hline $\begin{array}{l}\text { 13-cis-RA } \\
\text { 13-cis-RA }\end{array}$ & $\begin{array}{l}10^{-6} \\
10^{-5}\end{array}$ & $\begin{array}{l}6 \cdot 6(0.2) \\
5.9(0.5)\end{array}$ & $\begin{array}{l}98 \cdot 5 \\
88 \cdot 1\end{array}$ & $\begin{array}{l}\text { NS } \\
\text { NS }\end{array}$ \\
\hline $\begin{array}{l}\text { Ro } 10-9359 \\
\text { Ro } 10-9359\end{array}$ & $\begin{array}{l}10^{-6} \\
10^{-5}\end{array}$ & $\begin{array}{l}7 \cdot 5(0 \cdot 5) \\
7 \cdot(0)(0 \cdot 5)\end{array}$ & $\begin{array}{l}111 \cdot 9 \\
104 \cdot 5\end{array}$ & $\begin{array}{l}\text { NS } \\
\text { NS }\end{array}$ \\
\hline $\begin{array}{l}\text { All-trans-retinal } \\
\text { All-trans-retinal }\end{array}$ & $\begin{array}{l}10^{-6} \\
10^{-5}\end{array}$ & $\begin{array}{l}4 \cdot 5(0 \cdot 1) \\
3 \cdot 7((0 \cdot 1)\end{array}$ & $\begin{array}{l}67 \cdot 2 \\
55 \cdot 2\end{array}$ & $\begin{array}{l}<0 \cdot(05 \\
<0 \cdot(01\end{array}$ \\
\hline \multicolumn{5}{|l|}{ Experiment 2: } \\
\hline None (control) & -- & $3 \cdot 1(0 \cdot 1)$ & $100) \cdot 0$ & - \\
\hline $\begin{array}{l}\text { All-trans-RA } \\
\text { All-trans-RA }\end{array}$ & $\begin{array}{l}10^{-6} \\
10^{-5}\end{array}$ & $\begin{array}{l}2 \cdot 6(0 \cdot 1) \\
1 \cdot 2(0 \cdot 1)\end{array}$ & $\begin{array}{l}86 \cdot 0 \\
39 \cdot 4\end{array}$ & $\begin{array}{l}<(1) \cdot(1) 5 \\
<() \cdot(0) 1\end{array}$ \\
\hline $\begin{array}{l}\text { 13-cis-RA } \\
\text { 13-cis-RA }\end{array}$ & $\begin{array}{l}10^{-6} \\
10^{-5}\end{array}$ & $\begin{array}{l}2 \cdot 8(0 \cdot 2) \\
1 \cdot 8(0 \cdot 1)\end{array}$ & $\begin{array}{l}92 \cdot 2 \\
57 \cdot 7\end{array}$ & $\begin{array}{l}\text { NS } \\
<(1) \cdot(0) 1\end{array}$ \\
\hline $\begin{array}{l}\text { Ro } 10-9359 \\
\text { Ro } 10-9359\end{array}$ & $\begin{array}{l}10^{-6} \\
10^{-5}\end{array}$ & $\begin{array}{l}2 \cdot 8(0 \cdot 1) \\
1 \cdot 8(0 \cdot 1)\end{array}$ & $\begin{array}{l}92 \cdot 5 \\
56 \cdot 0\end{array}$ & $\begin{array}{l}\text { NS } \\
<(0 \cdot()(0)\end{array}$ \\
\hline $\begin{array}{l}\text { All-trans-retinal } \\
\text { All-trans-retinal }\end{array}$ & $\begin{array}{l}10^{-6} \\
10^{-5}\end{array}$ & $\begin{array}{l}2 \cdot 1(0 \cdot 1) \\
(0 \cdot 4(0 \cdot 1)\end{array}$ & $\begin{array}{l}69 \cdot 1 \\
14 \cdot 3\end{array}$ & $\begin{array}{l}<0 \cdot(0) 1 \\
<0 \cdot(0) 1\end{array}$ \\
\hline
\end{tabular}

${ }^{*}$ Adherent mononuclear cell cultures were established from peripheral blood of a patient with hacmochromatosis (experiment 1) or a healthy volunteer (experiment 2). The cells were incubated for $72 \mathrm{~h}$ in serum frec medium containing the retinoid in the final concentration indicated. The collagenase activity was then assayed as indicated in "Materials and methods". $+1 U$ equals $1 \mu$ g collagen degraded per minute: the values are expressed per mg cell protein in the same cultures (mean (SEM) of four parallel determinations).

$\ddagger$ Calculated by Student’s $t$ test: NS=statistically not significant. cells respectively (mean (SD); $\mathrm{p}>0 \cdot 10$ ). Also, noํㅡํ difference in the $\mathrm{LDH}$ activity released into the medium by cells incubated with or without $10^{-5} \mathrm{M}$ ? all-trans-RA was noted (results not shown). Thus there was no evidence of generalised inhibition of protein synthesis or cell membrane damage.

To examine the possibility that all-trans-RA might $\stackrel{\Phi}{\circledR}$ reduce the collagenase detectable in cell cultures medium by directly inhibiting the enzyme activity, medium from control cultures was assayed for collagenase activity directly in the presence of $10^{-5} \vec{\omega}$ - M all-trans-RA. The results indicated that theo enzyme activity was not altered in the presence of this retinoid, when compared with control incu-a bation containing the corresponding amount of ethanol.

In further studies the possibility that the retinoid might inhibit the secretion of collagenase from theo cells was examined by assaying the intracellularactivity. As indicated previously, ${ }^{16}$ very little, if any, $z$ intracellular enzyme activity was present in eithe control or all-trans-RA treated cells, excluding the possibility that the retinoid might interfere with the secretory process leading to collagenase accumula:tion in the cellular compartment.

Finally, mixing experiments were performed tos examine the possibility that the reduced collagenase activity noted in the retinoid treated cultures mighto result from induction of an inhibitory molecule $\varrho$ rather than from reduced collagenase production $\stackrel{\overrightarrow{0}}{0}$ Incubation of control medium with aliquots of media from cultures containing all-trans-RA showed that the enzyme activity present in the mixture was. the same as the added activities noted in eache medium when assayed alone. Furthermore, incuba $\frac{0}{5}$ tion of control medium with the homogenate of cells from cultures incubated with all-trans-RA did nots suggest the presence of an inhibitor molecule. Thus these observations suggest that all-trans-RA inhibits the collagenase production by adherent mononuc lear cells on the level of protein synthesis.

\section{EFFECTS OF OTHER RETINOIDS ON} COLLAGENASE PRODUCTION

Several additional retinoids were first tested in monocyte cultures established from the patient witk haemochromatosis for their effects on collagenase production. All-trans-retinal had a significant effect in the concentrations studied (Table 1, experimend 1). Somewhat surprisingly, $10^{-6}$ and $10^{-5} \mathrm{M} 13-$ cis $^{-}$ RA had no effect on collagenase production, while $62.5 \%$ reduction was noted with $10^{-4} \mathrm{M} 13$-cis- $\mathrm{RA} \stackrel{\mathrm{D}}{\mathrm{D}}$ This last concentration, however, is unphysiologie and may. have been toxic to the cells. Ro 10-935 had no effect in $10^{-6}$ or $10^{-5} \mathrm{~mol} / \mathrm{l}$ concentratio (Table 1, experiment 1). 
In contrast with the observations made in monocyte cultures from the patient with haemochromatosis, $10^{-5}$ M 13-cis-RA and Ro 10-9359 significantly reduced the collagenase production by normal monocyte cultures (Table 1, experiment 2). The degree of inhibition with these retinoids, however, was still less than that noted with all-trans-RA in the same cultures. All-trans-retinal had a marked inhibiting effect in both cultures.

\section{Discussion}

In the present study we have investigated the effect of retinoids on the production of collagenase by human adherent mononuclear cells in culture. The mononuclear cells from healthy controls synthesise and secrete collagenase only when activated by incubation with concanavalin $\mathrm{A} .{ }^{16}$ In addition, cells from a patient with haemochromatosis were studied; these cells are active in synthesising collagenase even without concanavalin A activation. The activation of collagenase production by the latter cells may be associated with increased serum iron concentration in the patient with haemochromatosis. ${ }^{22}$ Since monocyte-macrophage collagenase may contribute to the destruction of connective tissue components in rheumatoid arthritis the inhibition of collagenase production by retinoids such as all-trans-RA could potentially result in improvement of rheumatoid arthritis. Similar inhibition of collagenase production by all-trans-RA has been previously reported in human skin fibroblast and rheumatoid synovial cell cultures. $^{423-25}$

Previous animal studies examining the effects of retinoids when using collagen induced or adjuvant arthritis as experimental models for human rheumatoid arthritis have been conflicting. Specifically, treatment of adjuvant arthritic rats with 13-cis-RA resulted in considerable improvement of the tissue inflammation, ${ }^{3}$ yet an augmentation of the inflammatory process in the collagen induced arthritis model was observed. ${ }^{6}$ As indicated previously, ${ }^{3}$ the discrepancy in the effectiveness of 13-cis-RA in these two animal models of rheumatoid arthritis could have several explanations, including the retinoid dosage and the type of rats used. An alternative explanation could be offered based on the results of this study, showing that 13-cis-RA has a lesser effect on monocyte-macrophage collagenase production. In fact, monocyte cultures established from a patient with haemochromatosis were unresponsive to $10^{-5} \mathrm{M}$ 13-cis-RA, while collagenase production by the same cells was readily inhibited by all-trans-RA. The reasons for this discrepancy are not apparent, especially since all-trans-RA and 13-cis-RA share the same cellular binding receptors, at least in human skin fibroblasts. ${ }^{26}$ The differences in the postreceptor events between all-trans-RA and 13-cis-RA and their corresponding receptor complexes may explain the differential effect on the mononuclear cells of a patient with haemochromatosis. Thus if monocyte-macrophage collagenase has a predominant role in the inflammatory-destructive process of the collagen induced arthritis, lack of efficacy of this retinoid could be explained on the basis of predominant macrophage participation.

The exact mechanisms of the inhibition of collagenase production by all-trans-RA in mononuclear cell cultures are not clear at this point. Control experiments excluded, however, generalised inhibition of protein synthesis or induction of an inhibitor molecule as an explanation. Furthermore, no evidence of cell toxicity was noted, as monitored by the release of LDH activity into the extracellular milieu or assessed by viability of the cells by trypan blue exclusion. Furthermore, all-trans-RA appeared not to interfere with the secretion of collagenase from the cells. Thus it is conceivable that all-trans-RA inhibited the collagenase production on the transcriptional or translational level of protein synthesis. Previous studies have shown that the inhibition of collagen production in human skin fibroblast cultures by all-trans-RA is accompanied by a similar decrease in the level of type I procollagen messenger ribonucleic acid. ${ }^{24}$ Thus similar pretranslational mechanisms could be operative in modulating the collagenase production by retinoids in mononuclear cells in culture.

The authors wish to thank Charlene D Aranda for excellent secretarial assistance. This research was supported in part by USPHS, NIH grants AM-28450, GM-28833, and AM-35297, and by a grant from the Arthritis Foundation. Southern California Chapter.

\section{References}

1 Ohta A, Louie J S. Uitto J. Differential modulation of collagenase production by retinoids in human monocyte cultures [Abstract]. Clin Res 1986; 34: 164A.

2 Harris E D Jr. Retinoid therapy for rheumatoid arthritis. Ann Intern Med 1984: 100: 146-7.

3 Brinckerhoff C E. Coffey J W. Sullivan A C. Inflammation and collagenase production in rats with adjuvant arthritis reduced with 13-cis-retinoic acid. Science 1983: 221: 756-8.

4 Brinckerhoff C E. McMillan R M. Dayer J M. Harris E D Jr. Inhibition by retinoic acid of collagenase production in rheumatoid synovial cells. N Engl J Med 1980; 303: 432-6.

5 Brinckerhoff C E. Nagase H. Nagel J E. Harris E D Jr. Effects of all-trans-retinoic acid (retinoic acid) and 4hydroxyphenylretinamide on synovial cells and articular cartilage. J Am Acad Dermatol 1982: 6: 591-602.

6 Trentham D E. Brinckerhoff $\mathrm{C} \mathrm{E}$. Augmentation of collagen arthritis by synthetic analogues of retinoic acid. J Immunol 1982; 129: 2668-72

7 Strauss J S. Windhorst D B. Weinstein G D, Oral retinoids: a workshop. J Am Acad Dermatol 1982; 6 (suppl): 573-832. 
8 Goodman D S. Vitamin A and retinoids: recent advances. introduction. background, and general overview. Fed Proc 1979: 38: 2501-3.

9 Nathan C F. Murray H W. Cohn Z A. The macrophage as an effector cell. $N$ Engl J Med 1980: 303: 622-6.

10 Davies P. Bonney R J. Humes J L. Kuchl F A. Secretory functions of macrophages participating in inflammatory responses. In: Dingle J T. Gordon S. eds. Cellular interactions. Amsterdam: Elsevier/North Holland, 1981: 33-42.

11 Wahl L M. Wahl S M. Mergenhagen S E. Martin G R Collagenase production by endotoxin activated macrophages. Proc Natl Acad Sci USA 1974: 71: 3598-601.

12 Werb Z. Gordon S. Secretion of a specific collagenase by stimulated macrophages. J Exp Med 1975: 142: 346-60.

13 Horwitz A L. Crystal R G. Collagenase from rabbit pulmonary alveolar macrophages. Biochem Biophys Res Commun 1976: 69: $296-303$.

14 Mainardi C L. Scyer J M. Kang A H. Type specific collagenolysis: a type I collagen degrading enzyme from macrophages. Biochem Biophys Res (ommun 1980) 97: 1108-15.

15 Werb Z, Banda M J. Jones P A. Degradation of connective tissue matrices by macrophages. I. Proteolysis of elastin. glycoproteins and collagen by proteinases isolated from macrophages. J Exp Med 1980); 152: 1340)-57.

16 Louic J S. Weiss J, Ryhänen L. Nies K M. Rantala-Ryhänen S. Uitto $J$. The production of collagenase by adherent mononuclear cells cultured from human peripheral blood. Arthritis Rheum 1984; 27: 1397-404

17 Boyum A. Separation of leukocytes from blood and bone marrow. Scand J (lin l.ab Invest 1968: 21 (suppl 97) 77-89.
18 Ryhänen L. Rantala-Ryhänen S. Tan E M L Uitto J Assay o collagenase activity by a rapid. sensitive and specific method? Coll Relat Res 1982: 2: 117-30.

19 Phillips H J. Dye exclusion test for cell viability. In: Kruse P F Patterson M K Jr. eds. Tissue culture methods and applicationso New York: Academic Press. 1973: 4()6-8.

2) Wroblewski F. LaDuc J S. Lactic dehydrogenase activity in blood. Proc Soc Exp Biol Med 1955: 90: 210-3.

21 Bradford M M. A rapid and sensitive method for quantitation of microgram quantities of protein utilizing the principle of protein-binding dve. Anal Biochem 1976: 72: 248-54.

22 Okazaki I. Brinckerhoff ( $E$. Sinclair J F. Sinclair $P R \vec{D}$ Bonkowski 11 L.. Harris E D Jr. Iron increases collagenase:production by rabbit synovial fibroblasts. J I.ab (Clin Med 1981 97: $396-402$

23 Bauer E A. Seltzer J L. Eisen A Z. Retinoic acid inhibition oه̂ collagenase and gelatinasc expression in human skin fibroblasī cultures. Evidence for a dual mechanism. J Invest Dermatole 1983: 81: 102-69.

24 Oikarinen H. Oikarinen A I. Tan E M L. el al. Modulation of procollagen gene expression by retinoids: inhibition of collagener production by retinoic acid accompanied by reduced type $N$ procollagen messenger ribonucleic acid levels in human skin음 fibroblast cultures. J Clin Invest 1985: 75: 1545-53.

25 Abergel R P. Mecker ( A. Oikarinen H. Oikarinen A I, Uittor J. Retinoid modulation of connective tissuc metabolism in keloid fibroblast cultures. Arch Dermatol 1985: 121: 632-5.

26 Oikarinen A I. Oikarinen H. Uitto J. Demonstration of cellular $\vec{\bullet}$ retinoic acid binding protein in cultured human skin fibroblasts. Br J Dermatol 1985: 113: 529-35. 